\title{
HUBUNGAN PERAN KELUARGA DENGAN TINGKAT KECEMASAN ANAK USIA PRASEKOLAH SEBAGAI DAMPAK HOSPITALISASI DI RUANG MADINAH RUMAH SAKIT ISLAM SITI KHADIJAH PALEMBANG TAHUN 2016
}

\author{
Ibrahim Edy Sapada
}

Dosen Prodi S1 Keperawatan STIK Siti Khadijah Palembang

\begin{abstract}
ABSTRAK
Hospitalisasi merupakan suatu proses dimana karena alasan tertentu atau darurat mengharuskan anak untuk tinggal di rumah sakit, menjalani terapi perawatan, sampai dengan pemulangannya kembali ke rumah. Kecemasan pada anak prasekolah yang menjalani hospitalisasi merupakan salah satu bentuk gangguan akibat tidak terpenuhinya kebutuhan emosional anak yang adekuat. Keluarga mempunyai peran penting dalam perawatan anak. Salah satu peran penting keluarga adalah peran dalam pengasuhan atau perawatan. Penelitian ini bertujuan untuk mengetahui adakah hubungan peran keluarga dengan tingkat kecemasan anak usia prasekolah sebagai dampak hospitalisasi di ruang Madinah Rumah Sakit Islam Siti Khadijah Palembang Tahun 2016. Penelitian ini menggunakan teknik accidental sampling, dengan 30 responden yakni keluarga (orang tua) yang menjaga anak usia prasekolah yang dirawat di ruang Madinah RSI Siti Khadijah Palembang. Pengumpulan data dan pengisian kuesioner menggunakan metode wawancara. Uji korelasi yang digunakan adalah chi square. Hasil penelitian menunjukkan adanya hubungan peran keluarga dengan tingkat kecemasan anak usia prasekolah sebagai dampak hospitalisasi ( $p$ value $=0,013<0,05$ ). Diharapkan hasil penelitian ini dapat dijadikan sebagai acuan dan bahan pertimbangan perawat dalam melakukan intervensi keperawatan antara lain dengan melibatkan dan mendorong partisipasi keluarga (orang tua) dalam pengambilan keputusan terhadap intervensi keperawatan yang akan dilakukan. Selain itu, pada saat anak menjalani hospitalisasi hendaknya orang tua mampu mempersiapkan diri baik secara fisik maupun psikologis, sehingga peran pengasuhan atau perawatan dapat dilaksanakan dengan baik.
\end{abstract}

Kata Kunci

: Peran Keluarga, Kecemasan Anak, Hospitalisasi. 


\section{PENDAHULUAN}

Keperawatan anak merupakan disiplin ilmu kesehatan yang berfokus pada kesejahteraan anak. Anak merupakan individu yang berada dalam satu rentang perubahan perkembangan yang dimulai dari bayi hingga remaja. Anak diartikan sebagai individu yang berusia kurang dari delapan belas tahun yang sedang mengalami masa tumbuh kembang dengan kebutuhan khususnya yang meliputi kebutuhan fisik, psikologi, sosial dan spiritual, yang berbeda dengan orang dewasa. Anak usia prasekolah adalah mereka yang berada dalam rentang usia 3-6 tahun (Supartini, 2004). Disebut masa prasekolah karena anak mulai mempersiapkan diri memasuki dunia sekolah melalui kelompok bermain.

Hospitalisasi merupakan suatu proses dimana karena alasan tertentu atau darurat mengharuskan anak untuk tinggal di rumah sakit, menjalani terapi perawatan, sampai dengan pemulangannya kembali ke rumah (Supartini, 2004). Nursalam, dkk (2008) menjelaskan bahwa hospitalisasi ialah salah satu penyebab stres baik pada anak maupun keluarganya, terutama disebabkan oleh cemas akibat perpisahan dengan keluarga, perlukaan tubuh dan rasa sakit (nyeri), serta kehilangan kendali.

Angka kesakitan anak di Indonesia berdasarkan Survei Kesehatan Nasional (SUSENAS) tahun 2014 di daerah perkotaan menurut kelompok usia 0-2 tahun sebesar 25,8\%, usia 3-6 tahun sebanyak $14,91 \%$, usia 7-11 tahun sekitar 9,1\%, usia 12-18 tahun sebesar $8,13 \%$. Angka kesakitan anak usia 0 18 tahun apabila dihitung dari keseluruhan jumlah penduduk adalah 14,44\%. Anak yang mendapatkan perawatan di rumah sakit akan berpengaruh pada kondisi fisik dan psikologinya (Kementerian Kesehatan Republik Indonesia, 2014).

Berdasarkan data yang diperoleh dari Medical Record Rumah Sakit Islam Siti Khadijah Palembang pada tahun 2012 jumlah anak yang dirawat sebanyak 4.148 anak, tahun 2013 jumlah anak yang dirawat sebanyak 3.555 anak, tahun 2014 jumlah anak yang dirawat sebanyak 3.945 anak, pada tahun 2015 berjumlah 4081 anak. Sedangkan jumlah anak usia prasekolah yang menjalani hospitalisasi di ruang Madinah RSI Siti Khadijah Palembang pada bulan Maret 2016adalah sebanyak 40 anak.

Kecemasan adalah kekhawatiran yang tidak jelas dan menyebar, yang berkaitan dengan perasaan tidak pasti dan tidak berdaya (Stuart, 2006). Kecemasan pada anak prasekolah yang menjalani hospitalisasi merupakan salah satu bentuk gangguan akibat tidak terpenuhinya kebutuhan emosional anak yang adekuat. Usia prasekolah sangat rentan terhadap efek stres dan ketakutan selama rawat inap. Anak-anak dibawah usia enam tahun kurang mampu berpikir tentang suatu peristiwa secara keseluruhan, belum bisa menentukan perilaku yang dapat mengatasi suatu masalah yang baru dihadapi dan kurang memahami suatu peristiwa yang dialami (Jennet \& Peterson, 2002 dalam Winarsih, 2012). pAnak usia prasekolah belum mampu mengekspresikan emosi dan harapan mereka dengan cukup baik secara lisan.

Anak usia prasekolah mempersepsikan rawat inap di rumah sakit sebagai hukuman, sehingga anak merasa malu, bersalah atau takut. Hal ini dapat menimbulkan reaksi agresif dengan marah dan berontak, ekspresi verbal dengan mengucapkan kata-kata marah, dan tidak mau bekerja sama dengan perawat serta 
ketergantungan dengan orang tua. Apabila kondisi ini terjadi, maka akan memengaruhi proses perawatan anak saat berada di rumah sakit (Supartini, 2004).

Sebagai bahan perbandingan, anak usia toddler bereaksi terhadap hospitalisasi sesuai dengan sumber stresnya. Sumber stres yang utama baginya adalah cemas akibat perpisahan. Respon perilaku anak sesuai dengan tahapannya, yaitu tahap protes, putus asa, dan pengingkaran (denia). Pada tahap protes, perilaku yang ditunjukkan adalah menangis kuat, memanggil orang tua atau menolak perhatian dari orang lain. Pada tahap putus asa, perilaku yang ditunjukkan adalah menangis berkurang, anak tidak aktif, kurang menunjukkan minat untuk bermain dan makan, sedih, dan apatis. Kelebihannya terletak pada tahap pengingkaran, karena pada tahap ini perilaku yang ditunjukkan adalah secara samar anak mulai menerima perpisahan, membina hubungan secara dangkal, dan mulai menyukai lingkungannya (Supartini, 2004). Sedangkan pada anak usia sekolah, reaksi terhadap perlukaan atau rasa nyeri akan ditunjukkan dengan ekspresi baik secara verbal maupun nonverbal karena anak sudah mampu mengomunikasikannya. Selain itu, anak usia sekolah sudah mampu mengontrol perilakunya, sebagai contoh jika merasa nyeri, ia akan mengontrolnya dengan cara menggigit bibir, atau dengan memegang sesuatu dengan erat (Supartini, 2004).

Prevalensi gangguan kecemasan yang terjadi pada anak usia prasekolah yang menjalani hospitalisasi hasil penelitian Murniasih dan Rahmawati (2007), menunjukkan bahwa dari 30 responden anak usia prasekolah yang dirawat di Bangsal L RSUP Dr. Soeradji Tirtonegoro Klaten yang mengalami cemas berat 4 orang $(13,33 \%)$, cemas sedang 17 responden (56,66\%), cemas ringan 8 responden $(26,66 \%)$, dan tidak cemas 1 orang $(3.33 \%)$.

Berdasarkan survei pendahuluan yang dilakukan peneliti melalui wawancara dengan beberapa orang tua yang anaknya dirawat di ruang Madinah Rumah Sakit Islam Siti Khadijah Palembang, menunjukkan adanya indikasi kecemasan yang bervariasi pada anak mereka. Indikasi tersebut didapatkan berdasarkan keterangan orang tua yang mengatakan bahwa anaknya sering menunjukkan reaksi penolakkan seperti menjerit, menangis dan menolak untuk dilakukan tindakan keperawatan oleh perawat atau petugas kesehatan lainnya.

Kecemasan yang terjadi pada anak tidak bisa dianggap remeh, mengingat hal tersebut dapat berdampak buruk pada proses pemulihaan kesehatan anak. Penatalaksanaan untuk mengurangi kecemasan pada anak yang menjalani perawatan di rumah sakit sangat diperlukan, diantaranya dengan melibatkan dan mendorong partisipasi orang tua (Wong, 2008).

Keluarga mempunyai peran penting dalam perawatan anak, mengingat anak merupakan bagian dari keluarga. Salah satu peran penting keluarga adalah peran dalam pengasuhan atau perawatan, yang mana pada dasarnya tujuan utama pengasuhan atau perawatan keluarga (orang tua) adalah mempertahankan kehidupan fisik anak dan meningkatkan kesehatannya, memfasilitasi anak untuk mengembangkan kemampuan sejalan dengan tahap perkembangannya dan mendorong peningkatan kemampuan berperilaku sesuai dengan nilai agama dan budaya yang diyakininya. Berkaitan dengan pengasuhan atau perawatan anak di rumah sakit, Canam (1993) dalam Supartini (2004) 
membuktikan bahwa tugas yang dijalankan keluarga secara adaptif dalam pengasuhan atau perawatan anak di rumah sakit sangat memengaruhi dalam pencapaian tujuan pengasuhan atau perawatan anak, adapun tugas adaptif yang dimaksud yakni, menerima kondisi anak, mengelola kondisi anak, memenuhi kebutuhan perkembangan anak, memenuhi kebutuhan perkembangan keluarga, menghadapi stresor dengan positif, membantu anggota keluarga untuk mengelola perasaan yang ada, mendidik anggota keluarga yang lain tentang kondisi anak yang sedang sakit, dan mengembangkan sistem dukungan sosial (Supartini, 2004).

Hasil penelitian yang dilakukan oleh Aidar (2011) dengan judul "Hubungan Peran Keluarga dengan Tingkat Kecemasan Anak Usia Sekolah (6-12 Tahun) yang Mengalami Hospitalisasi Di Ruang III Rumah Sakit Umum dr. Pirngadi Medan", berdasarkan hasil penelitian dengan uji Spearman Rho diperoleh nilai $p$ sebesar $0,041 \quad(p<0,05)$ yang menunjukkan ada hubungan yang bermakna antara peran keluarga dengan tingkat kecemasan anak usia sekolah yang mengalami hospitalisasi.

Berangkat dari latar belakang tersebut, maka peneliti tertarik untuk mengambil judul penelitian "Hubungan Peran Keluarga dengan Tingkat Kecemasan Anak Usia Prasekolah Sebagai Dampak Hospitalisasi di Ruang Madinah Rumah Sakit Islam Siti Khadijah Palembang Tahun 2016".

\section{METODE PENELITIAN}

Desain penelitian ini menggunakan metode survei analitik dengan menggunakan pendekatan "cross sectional". Pada penelitian ini hanya dilihat hubungan kedua variabel yakni peran keluarga dengan tingkat kecemasan anak usia prasekolah sebagai dampak hospitalisasi.

Populasi dalam penelitian ini adalah seluruh orang tua yang anaknya menjalani hospitalisasi di ruang Madinah Rumah Sakit Islam Siti Khadijah Palembang. Jumlah populasi anak usia prasekolah yang menjalani hospitalisasi di ruang Madinah Rumah Sakit Islam Siti Khadijah Palembang pada bulan Maret 2016 adalah sebanyak 40 orang. Sampel yang digunakan dalam penelitian adalah seluruh orang tua yang anaknya (usia prasekolah) menjalani hospitalisasi di ruang Madinah RSI Siti Khadijah Palembang dari tanggal 11 April sampai dengan 30 April 2016. Pengambilan sampel secara non probability sampling dengan teknik accidental sampling. Adapun jumlah sampel dalam penelitian ini sebanyak 30 responden.

Instrumen yang digunakan dalam penelitian ini adalah lembar kuesioner peran keluarga dan lembar kuesioner tingkat kecemasan HARS (Hamilton Anxiety Rating Scale) hasil modifikasi. Untuk pengukuran peran keluarga, digunakan lembar kuesioner yang terdiri dari 24 pernyataan yang merupakan pengembangan dari 8 tugas adaptif keluarga pada saat anak menjalani perawatan di rumah sakit yang sebelumnya telah digunakan pada penelitian yang dilakukan oleh Aidar (2011). Masing-masing kelompok pernyatan diberi penilaian antara 1-4 dengan penilaian: nilai 1 (Tidak Pernah/TP), nilai 2 (Kadang-kadang/KK), nilai 3 (Sering/SR), dan nilai 4 (Selalu/SL). Adapun untuk penilaiannya, masing - masing skor dari 24 pernyataan dijumlahkan, dari hasil penjumlahan tersebut dapat diketahui kategori peran keluarga adalah sebagai berikut : 1 . Baik, jika nilainya $\geq 78$ 
(Median) dan Kurang baik, jika nilainya <78 (Median). Sedangkan, untuk pengukuran tingkat kecemasan digunakan kuesioner kecemasan HARS (Hamilton Anxiety Rating Scale) yang dimodifikasi menjadi 16 pernyataan disesuaikan dengan kondisi anak yang menjalani hospitalisasi, masing-masing kelompok pernyataan diberi penilaian antara 1 4 dengan penilaian sebagai berikut: Nilai 1 (tidak pernah), 2 (kadang-kadang), 3 (sering), dan 4 (selalu). Adapun untuk penilaiannya, masing-masing skor dari 16 pernyataan dijumlahkan, dari hasil penjumlahan tersebut dapat diketahui derajat kecemasan seseorang adalah sebagai berikut : 1.1-16 (Kecemasan Ringan), 2.17-32 (Kecemasan Sedang), 3. 3348 (Kecemasan Berat), dan 4. 49-64 (Kecemasan Berat Sekali/Panik).

Pengolahan data dimulai dari tahap editing, coding, memasukkan data (entry), sampai dengan pembersihan data (cleaning).

Analisis data yang digunakan dalam penelitian ini adalah analisis univariat dan bivariat. Analisis univariat dilakukan untuk melihat distribusi frekuensi peran keluarga dan tingkat kecemasan anak usia prasekolah. Sedangkan analisis bivariat dilakukan untuk melihat hubungan antara dua variabel yakni variabel independen (peran keluarga) dengan variabel dependen (tingkat kecemasan anak usia prasekolah). Untuk menguji tingkat kemaknaan dilakukan uji statistik chi square $\left(\mathrm{X}^{2}\right)$ dengan sistem komputerisasi, dengan luas batas kemaknaan $\alpha=0,05$. Jika $p$ value $<0,05$, artinya ada hubungan bermakna antara kedua variabel tersebut. Sebaliknya, jika ditemukan $\mathrm{p}$ value $>0.05$, artinya tidak ada hubungan bermakna antara kedua variabel.

\section{HASIL PENELITIAN}

Analisis Univariat

1. Tingkat Kecemasan (V. Dependen)

Tabel 5.1

Distribusi Frekuensi Tingkat Kecema- san Anak Usia Prasekolah sebagai Dampak Hospitalisasi di Ruang Madinah RSI Siti Khadijah Palembang Tahun 2016

\begin{tabular}{|c|c|c|c|}
\hline No & $\begin{array}{c}\text { Tingkat } \\
\text { Kecemasan }\end{array}$ & $\mathrm{n}$ & $\%$ \\
\hline 1 & $\begin{array}{c}\text { Kecemasan } \\
\text { Sedang }\end{array}$ & 18 & 60 \\
\hline 2 & $\begin{array}{c}\text { Kecemasan } \\
\text { Berat }\end{array}$ & 12 & 40 \\
\hline \multicolumn{2}{|c|}{ Total } & 30 & 100 \\
\hline
\end{tabular}

Dari tabel 5.1 dapat diketahui bahwa dari 30 responden, yang mempunyai tingkat kecemasan kategori sedang sebanyak 18 responden (60\%) lebih banyak dibandingkan dengan tingkat kecemasan kategori berat, yakni sebanyak 12 responden (40\%).

2. Peran Keluarga (V. Independen)

Tabel 5.2

Distribusi Frekuensi Peran Keluarga Anak Usia Prasekolah yang Menjala- ni Hospitalisasi di Ruang Madinah RSI Siti Khadijah Palembang

Tahun 2016

\begin{tabular}{|c|c|c|c|}
\hline No & $\begin{array}{c}\text { Peran } \\
\text { Keluarga }\end{array}$ & $n$ & $\%$ \\
\hline 1 & Baik & 17 & 56,7 \\
\hline 2 & Kurang Baik & 13 & 43,3 \\
\hline \multicolumn{2}{|c|}{ Total } & 30 & 100 \\
\hline
\end{tabular}

Dari tabel 5.2 dapat diketahui bahwa dari 30 responden, yang mempunyai peran keluarga kategori baik sebanyak 17 responden $(56,7 \%)$, lebih banyak dibandingkan peran keluarga kategori kurang baik sebanyak 13 responden $(43,3 \%)$. 


\section{Analisis Bivariat}

1. Hubungan Peran Keluarga dengan Tingkat Kecemasan Anak Usia Prasekolah.
Tabel 5.3

Hubungan Peran Keluarga dengan Tingkat

Kecemasan Anak Usia Prasekolah sebagai

Dampak Hospitalisasi di Ruang Madinah

RSI Siti Khadijah Palembang

Tahun 2016

\begin{tabular}{|c|c|c|c|c|c|c|c|c|c|}
\hline \multirow{3}{*}{ No } & \multirow{3}{*}{$\begin{array}{l}\text { Peran } \\
\text { Keluarga }\end{array}$} & \multicolumn{4}{|c|}{$\begin{array}{l}\text { Tingkat Kecemasan Anak Usia } \\
\text { Prasekolah }\end{array}$} & \multirow{2}{*}{\multicolumn{2}{|c|}{ Total }} & $p$ value & OR \\
\hline & & \multicolumn{2}{|c|}{$\begin{array}{l}\text { Kecemasan } \\
\text { Sedang }\end{array}$} & \multicolumn{2}{|c|}{$\begin{array}{l}\text { Kecemasan } \\
\text { Berat }\end{array}$} & & & \multirow{5}{*}{0,013} & \multirow{5}{*}{10,5} \\
\hline & & $n$ & $\%$ & $n$ & $\%$ & $\mathbf{n}$ & $\%$ & & \\
\hline 1 & Baik & 14 & 82,4 & 3 & 17,6 & 17 & 100 & & \\
\hline \multirow[t]{2}{*}{2} & $\begin{array}{c}\text { Kurang } \\
\text { Baik }\end{array}$ & 4 & 30,8 & 9 & 69,2 & 13 & 100 & & \\
\hline & Total & 18 & - & 12 & - & 30 & - & & \\
\hline
\end{tabular}

Dari Tabel 5.3 dapat diketahui bahwa dari 13 responden, yang memiliki peran keluarga kategori kurang baik dengan tingkat kecemasan berat sebanyak 9 responden $(69,2 \%)$, lebih banyak dibandingkan dengan responden yang memiliki peran keluarga kategori baik dengan tingkat kecemasan berat sebanyak 3 responden (17,6\%).

Hasil uji statistik pada taraf signifikansi $5 \%$ didapatkan nilai $\mathrm{p}$ value $=0,013<\alpha(0,05)$ menunjukkan bahwa ada hubungan peran keluarga dengan tingkat kecemasan anak usia prasekolah sebagai dampak hospitalisasi di ruang Madinah RSI Siti Khadijah Palembang Tahun 2016. Hasil analisis juga diperoleh nilai $\mathrm{OR}=10,5$ artinya responden yang memiliki peran keluarga kategori kurang baik berpeluang 10,5 kali untuk menjadikan tingkat kecemasan anak terletak pada taraf kecemasan berat dibandingkan dengan responden yang memiliki peran keluarga kategori baik.

\section{PEMBAHASAN}

\section{Pembahasan Univariat}

1. Tingkat Kecemasan
Berdasarkan hasil penelitian yang dilakukan di ruang Madinah RSI Siti Khadijah Palembang Tahun 2016 didapatkan dari 30 responden tingkat kecemasan anak usia prasekolah kategori kecemasan sedang sebanyak 18 orang $(60 \%)$, lebih banyak dibandingkan dengan tingkat kecemasan kategori beratyakni sebanyak 12 orang (40\%).

Hospitalisasi merupakan suatu proses dimana karena alasan tertentu atau darurat mengharuskan seorang anak untuk tinggal di rumah sakit, menjalani terapi perawatan sampai pemulangannya kembali ke rumah (Supartini, 2004). Hospitalisasi menjadi salah satu penyebab stres baik pada anak maupun keluarganya (Nursalam, dkk, 2008).Pada saat anak menjalani hospitalisasi, anak akan menunjukkan berbagai perilaku sebagai reaksi terhadap pengalaman hospitalisasi. Reaksi tersebut bersifat individual, dan sangat bergantung pada tahapan usia perkembangan anak, pengalaman sebelumnya terhadap sakit, sistem pendukung yang tersedia, dan kemampuan koping yang dimilikinya. Pada umumnya, reaksi anak terhadap sakit adalah kecemasan karena perpisahan, kehilangan kontrol, perlukaan tubuh, dan rasa nyeri. 
Setiap anak memiliki reaksi yang berbeda-beda terhadap hospitalisasi sesuai dengan tahap perkembangannya. Pada anak usia lebih dari 6 bulan terjadi stranger anxiety atau cemas apabila berhadapan dengan orang yang tidak dikenalnya. Reaksi yang sering muncul pada anak ini adalah menangis, marah, dan banyak melakukan gerakan sebagai sikap stranger. Anak usia toddler (1-3 tahun) bereaksi sesuai dengan sumber stresnya yakni cemas akibat perpisahan. Respon perilaku yang ditampilkan sesuai dengan tahapannya. Menangis kuat, memanggil orang tua, atau menolak perhatian dari orang lain (tahap protes), menangis berkurang, anak tidak aktif, kurang minat bermain dan makan, sedih, dan apatis (tahap putus asa), dan mulai menerima perpisahan, membina hubungan secara dangkal, dan mulai menyukai lingkungannya (tahap pengingkaran). Pada anak usia sekolah (6-12 tahun), reaksi yang ditimbulkan yakni kecemasan akibat perpisahan dengan keluarga dan terutama kelompok sosialnya, perasaan takut mati dan adanya kelemahan fisik (kehilangan kontrol), serta reaksi anak terhadap perlukaan dan nyeri ditunjukkan dengan ekspresi baik secara verbal maupun verbal karena anak sudah mampu mengomunikasikannya. Anak usia sekolah sudah mampu mengontrol perilakunya jika merasa nyeri, yakni dengan menggigit dan memegang sesuatu dengan erat. Pada anak usia remaja (12-18 tahun), reaksi yang ditimbulkan adalah cemas akibat perpisahan dengan teman sebaya (geng), kehilangan kontrol akibat pembatasan aktivitas sehingga anak menjadi bergantung pada keluarga maupun petugas kesehatan di rumah sakit, anak juga akan menolak perawatan atau tindakan yang dilakukan padanya, anak menjadi tidak kooperatif, dan menarik diri, perasaan sakit karena perlukaan atau pembedahan menimbulkan respon anak bertanya-tanya, menarik diri dari lingkungan, dan atau menolak kehadiran orang lain (Supartini, 2004).

$$
\text { Anak usia prasekolah }
$$

tahun)mempersepsikan rawat inap di rumah sakit sebagai hukuman, sehingga anak merasa malu, bersalah atau takut. Hal ini dapat menimbulkan reaksi agresif dengan marah dan berontak, ekspresi verbal dengan mengucapkan kata-kata marah, dan tidak mau bekerja sama dengan perawat serta ketergantungan dengan orang tua (Supartini, 2004). Selain itu anak usia prasekolah sangat rentan terhadap efek stres dan ketakutan selama rawat inap. Anak-anak dibawah usia enam tahun kurang mampu berpikir tentang suatu peristiwa secara keseluruhan, belum bisa menentukan perilaku yang dapat mengatasi suatu masalah yang baru dihadapi dan kurang memahami suatu peristiwa yang dialami (Jennet \& Peterson, 2002 dalam Winarsih, 2012).

Selain faktor umur dan perkembangan kognitif, terdapat faktor-faktor lain yang turut mempengaruhi reaksi anak terhadap hospitalisasi, antara lain respon orang tua, persiapan anak dan orang tua, serta keterampilan koping anak.

Hasil ukur tingkat kecemasan yang ada di dalam teori mengatakan bahwa kecemasan dibagi menjadi 5 kategori, yakni tidak cemas, cemas ringan, cemas sedang, cemas berat, dan cemas sangat berat/panik (Stuart, 2006), sedangkan hasil penelitian yang didapat hanya ada 2 kategori saja, yakni cemas sedang dan cemas berat. 
Hasil penelitian ini sejalan dengan penelitian yang dilakukan oleh Murniasih dan Rahmawati (2007), menunjukkan bahwa dari 30 responden anak usia prasekolah yang dirawat di Bangsal L RSUP Dr. Soeradji Tirtonegoro Klaten yang mengalami cemas berat 4 orang $(13,33 \%)$, cemas sedang 17 orang $(56,66 \%)$, cemas ringan 8 orang (26,66\%), dan tidak cemas 1 orang (3.33\%).

Peneliti berasumsi bahwa tingkat kecemasan anak usia prasekolah yang menjalani hospitalisasi di ruang Madinah RSI Siti Khadijah Palembang masih cukup tinggi, hal tersebut dibuktikan dari hasil analisis univariat variabel dependen (tingkat kecemasan anak usia prasekolah) hanya terdapat dua kategori tingkat kecemasan saja yakni kecemasan sedang dan kecemasan berat.Hal ini membuktikan bahwa anak usia prasekolah memang sangat rentan terhadap efek stres dan ketakutan selama rawat inap. Hanya saja interval antara cemas sedang dan cemas berat tidak terlalu jauh dengan rincian kategori cemas sedang lebih banyak dibandingkan dengan kategori cemas berat, hal tersebut terjadi bisa karena adanya faktor lain yang turut mempengaruhi. Salah satu faktor yang memengaruhinya yakni adanya support system dalam hal ini pendampingan orang tua selama perawatan. Kecemasan yang dirasakan anak dapat disebabkan oleh keadaan anak yang sakit, lingkungan serta ruang perawatan anak, tenaga kesehatan yang belum pernah ditemui anak sebelumnya dan proses perawatan itu sendiri.Strategi yang dapat dilakukan untuk mengurangi tingkat kecemasan anak pada saatmenjalani hospitalisasiantara lain dukungan orang tua yang selalu menemani anak selama menjalani perawatan, membantu anak untuk mengenal lingkungan serta ruang perawatan, melatih kemampuan perawat dalam berkomunikasi dengan anak secara baik, serta menciptakan suasana di rumah sakit layaknya seperti suasana di rumah.

\section{Peran Keluarga}

Pada variabel peran keluarga digunakan uji normalitas shapiro wilk $(\mathrm{N}<50)$, didapatkan nilai $0,020<0,05$, artinya data terdistribusi tidak normal. Sehingga penentuan peran keluarga kategori baik dan kurang baik menggunakan nilai median yakni 78. Berdasarkan hasil penelitian yang dilakukan di ruang Madinah RSI Siti Khadijah Palembang Tahun 2016 didapatkan dari 30 responden, peran keluarga kategori baik sebanyak 17 responden $(56,7 \%)$, lebih banyak dibandingkan dengan peran keluarga kategori kurang baik yakni sebanyak 13 orang $(43,3 \%)$.

Keluarga adalah kumpulan dua orang atau lebih yang disatukan oleh ikatan-ikatan kebersamaan dan ikatan emosional dan yang mengidentifikasikan diri mereka sebagai bagian dari keluarga (Friedman, 1998). Peran diartikan sebagai kemampuan individu untuk mengontrol, memengaruhi, atau mengubah perilaku orang lain. Peran anggota keluarga dijalankan untuk menjaga keseimbangan dalam keluarga, yang dijalankan melalui peran formal maupun informal. Dalam konteks peran formal, Nye dan Gecas (1976), dalam Supartini (2004), mengemukakan bahwa beberapa peran dasar laki-laki sebagai ayah dan wanita sebagai ibu yang mempunyai posisi sosial sebagai pemberi layanan, yaitu peran penjaga rumah, peran pemeliharaan anak, peran sosialisasi anak, peran rekreasi, mempertahankan hubungan dengan keluarga wanita atau laki-laki, pemenuhan kebutuhan 
pasangan, dan peran seksual. Sedangkan peran informal dari keluarga lebih bersifat adaptif dan mempertahankan kesejahteraan keluarga. Peran informal adalah peran sebagai pemberi dorongan, peran mempertahankan keharmonisan, peran untuk kompromi, peran untuk memulai atau berkontribusi dalam menghadapi masalah, peran untuk pelopor, koordiantor, dan peran informal lainnya. Berkaitan dengan proses hospitalisasi anak, salah satu peran penting keluarga adalah peran dalam pengasuhan atau peran perawatan, yang mana pada dasarnya tujuan utama pengasuhan atau perawatan keluarga adalah mempertahankan kehidupan fisik anak dan meningkatkan kesehatannya, memfasilitasi anak untuk mengembangkan kemampuan sejalan dengan tahap perkembangannya dan mendorong peningkatan kemampuan berperilaku sesuai dengan nilai agama dan budaya yang diyakininya (Supartini, 2004).

Berkaitan dengan perawatan anak di rumah sakit, Canam (1993) dalam Supartini (2004), membuktikan bahwa tugas yang dijalankan keluarga secara adaptif dalam pengasuhan atau perawatan anak di rumah sakit sangat memengaruhi dalam pencapaian tujuan pengasuhan atau perawatan anak. Peran pengasuhan atau perawatan anak dikatakan baik apabila keluarga mampu menjalankan delapan tugas adaptif yang menjadi indikatornya, yakni menerima kondisi anak, mengelola kondisi anak, memenuhi kebutuhan perkembangan anak, memenuhi kebutuhan perkembangan keluarga, menghadapi stresor dengan positif, membantu anggota keluarga untuk mengelola perasaan yang ada, mendidik anggota keluarga yang lain tentang kondisi anak yang sedang sakit, dan mengembangkan sistem dukungan sosial.
Hasil penelitian ini sejalan dengan penelitian yang dilakukan oleh Aidar pada tahun 2011 di ruanglll Rumah Sakit Umum Dr. Pringadi Medan dengan jumlah sampel 33 AnakUsia Sekolah (6-12 tahun) yang mengalami hospitalisasi, dari 33 responden didapatkan peran keluarga dengan kategori baik sebanyak 5 responden (13,3\%), peran keluarga dengan kategori cukupsebanyak 29 responden $(80,6 \%)$, dan peran keluarga dengan kategori kurang baik sebanyak 2 responden (5,6\%).

Berdasarkan data di atas peneliti berasumsi bahwa Peran yang dijalankan keluarga (orang tua) yang anaknya menjalani hospitalisasi di ruang Madinah RSI Siti Khadijah Palembang sudah cukup baik namun belum optimal, hal ini dibuktikan dari hasil analisis univariat variabel independen (peran keluarga anak usia prasekolah) didapatkan hasil peran keluarga kategori baik lebih banyak dibandingkan dengan peran keluarga kategori kurang baik.Hanya saja interval antara peran keluarga kategori baik dan peran keluarga kategori kurang baik tidak terlalu signifikan. Hal tersebut terjadi karena adanya faktor lain yang turut mempengaruhi, bisa karena usia orang tua, keterlibatan ayah, pendidikan orang tua, pengalaman sebelumnya dalam mengasuh anak, stres orang tua, dan hubungan suami istri.

Peran keluarga yang dijalankan selama menjalani perawatan di rumah sakit tak lepas dari dukungan perawat terhadap keluarga yang sangat dibutuhkan untuk mengoptimalkan peran tersebut. Strategi yang dapat dilakukan perawat untuk memanajemen orang tua saat anak dirawat di rumah sakit antara lain dengan mensosialisasikan lingkungan rawat dan perawatan yang akan dijalani anak serta 
melibatkan dan mendorong partisipasi keluarga dalam pengambilan keputusan tindakan yang akan diterima anak.

\section{Pembahasan Bivariat}

1. Hubungan Peran Keluarga dengan Tingkat Kecemasan Anak Usia Prasekolah

Pada penelian ini jumlah responden yang memiliki peran keluarga yang baik dengan tingkat kecemasan sedang lebih tinggi yakni sebanyak 14 orang $(82,4 \%)$, dibandingkan dengan responden yang memiliki peran keluarga yang kurang baik dengan tingkat kecemasan sedang sebanyak 4 orang $(30,8 \%)$. Hasil uji statistik Chi Square pada taraf signifikansi $5 \%$ didapatkan $p$ value $=0,013<\alpha$ $(0,05)$ menunjukkan bahwa ada hubungan peran keluarga dengan tingkat kecemasan anak usia prasekolah sebagai dampak hospitalisasi di ruang Madinah RSI Siti Khadijah Palembang Tahun 2016. Hasil analisis juga diperoleh nilai $\mathrm{OR}=10,5$, artinya responden yang memiliki peran baik berpeluang 10,5 kali untuk menjadikan tingkat kecemasan anak terletak pada taraf sedang dibandingkan dengan responden yang memiliki peran kurang baik pada saat anak menjalani hospitalisasi.

Semakin baik peran keluarga semakin besar kemungkinan untuk meminimalisasi tingkat kecemasan anak usia prasekolah pada saat menjalani hospitalisasi. Sebagaimana yang diungkapkan oleh Supartini (2004) bahwa salah satu peran penting keluarga adalah peran dalam pengasuhan atau perawatan, yang mana pada dasarnya tujuan utama pengasuhan atau perawatan keluarga (orang tua) adalah mempertahankan kehidupan fisik anak dan meningkatkan kesehatannya, memfasilitasi anak untuk mengembangkan kemampuan sejalan dengan tahap perkembangannya dan mendorong peningkatan kemampuan berperilaku sesuai dengan nilai agama dan budaya yang diyakininya.

Hasil penelitian ini sejalan dengan penelitian yang dilakukan oleh Aidar pada tahun 2011 di ruanglll Rumah Sakit Umum Dr. Pringadi Medan dengan jumlah sampel 33 Anak Usia Sekolah (6-12 tahun) yang mengalami hospitalisasi. Pada penelitianmenggunakan uji koefisien korelasi Spearman (Correlations Spearman's Rho).Berdasarkan hasil penelitian diperoleh nilai $\quad p \quad$ sebesar $0,041 \quad(p<0,05)$ yangmenunjukkan ada hubungan yang bermakna antara peran keluarga dengantingkat kecemasan anak usia sekolah yang mengalami hospitalisasi. Kekuatan korelasi yakni $(r)=$ 0,342 yang mengidentifiksasikan bahwa kekuatan hubungan peran keluarga dengan tingkat kecemasan anak usia sekolah yang mengalamihospitalisasi dalam kategori sedang. Dengan arah korelasi (-) artinya semakin tinggi peran keluarga, maka semakin rendahtingkat kecemasan anak usia sekolah yang mengalami hospitalisasi.

Berdasarkan hasil penelitian dan uraian teori di atas, peneliti berasumsi bahwa pada dasarnya peran mampu mengontrol, memengaruhi, atau mengubah perilaku orang lain. Dalam hal perawatan anak di rumah sakit, selain adanya peran perawat dan petugas kesehatan lainnya keterlibatan keluarga khususnya orang tua sangat dibutuhkan guna meminimalisasi dampak negatif yang ditimbulkan pada saat anak menjalani hospitalisasi. Kecemasan yang timbul pada anak usia prasekolah disebabkan karena anak 
usia prasekolah mempersepsikan hospitalisasi sebagai hukuman sehingga anak akan merasa malu, bersalah, atau takut. Ketakuan anak terhadap perlukaan muncul karena anak menganggap tindakan dan prosedurnya mengancam integritas tubuhnya. Oleh karena itu, hal ini menimbulkan reaksi agresif dengan marah dan berontak, ekspresi verbal dengan mengucapkan kata - kata marah, tidak mau bekerja sama dengan perawat, dan ketergantungan pada orang tua. Peran keluarga diharapkan mampu mengatasi atau paling tidak meminimalisasi dampak tersebut.

\section{SIMPULAN}

Dari hasil penelitian yang dilakukan di ruang Madinah RSI Siti Khadijah Palembang Tahun 2016, maka kesimpulan yang dapat ditarik adalah sebagai berikut:

1. Diketahui bahwa dari 30 responden, yang mempunyai tingkat kecemasan kategori sedang sebanyak 18 responden (60\%) lebih banyak dibandingkan dengan tingkat kecemasan berat, yakni sebanyak 12 responden (40\%).

2. Diketahui bahwa dari 30 responden, yang mempunyai peran keluarga kategori baik sebanyak 17 responden (56,7\%), lebih banyak dibandingkan peran keluarga kategori kurang baik sebanyak 13 responden (43,3\%).

3. Adanya hubungan peran keluarga dengan tingkat kecemasan anak usia prasekolah sebagai dampak hospitalisasi di ruang Madinah RSI Siti Khadijah Palembang Tahun 2016 dengan hasil $p$ value $=0,013<0,05$.

\section{SARAN}

1. Bagi RSI Siti Khadijah Palembang
Diharapkan hasil penelitian ini dapat dijadikan sebagai acuan dan bahan pertimbangan perawat dalam melakukan intervensi keperawatan. Perawat di ruang perawatan anak sebaiknya mampu meningkatkan hubungan yang baik terhadap keluarga (orang tua) maupun anak. Perawat juga hendaknya tidak ragu-ragu untuk memberikan segala informasi tentang kondisi anak mulai dari anak masuk rumah sakit sampai pulang kembali ke rumah. Selain itu pada saat pelaksanaan perawatan sebaiknya perawat melibatkan dan mendorong partisipasi keluarga (orang tua) dalam pengambilan keputusan terhadap intervensi keperawatan yang akan dilakukan. Keterlibatan orang tua diharapkan dapat menimbulkan perasaan nyaman pada anak dan tingkat kecemasan pun diharapkan dapat diminimalisasi.

\section{Bagi Orang Tua}

Pada saat anak menjalani hospitalisasi hendaknya orang tua mampu mempersiapkan baik secara fisik maupun psikologis, sehingga peran pengasuhan khususnya pada saat anak menjalani hospitalisasi dapat dilaksanakan dengan baik. Orang tua juga diharapkan untuk senatiasa ikut terlibat dan berpartisipasi terhadap pengambilan keputusan khususnya pada saat anak hendak menjalani tindakan keperawatan. Dengan adanya keterlibatan dan partisipasi orang tua diharapkan dapat memunculkan perasaan nyaman pada anak dan diharapkan mampu meminimalisasi dampak negatif hospitalisasi yang salah satunya adalah kecemasan pada anak.

3. Bagi Peneliti Selanjutnya

Diharapkan hasil penelitian ini dapat dijadikan bahan acuan dan bahan 
perbandingan untuk melakukan penelitian selanjutnya mengenai faktor-faktor lain yang dapat memengaruhi tingkat kecemasan anak akibat hospitalisasi atau dengan judul yang sama yakni hubungan peran keluarga dengan tingkat kecemasan anak, namun dengan kategori usia anak yang berbeda dengan jumlah sampel yang diambil lebih besar daripada penelitian ini.

\section{DAFTAR PUSTAKA}

Aidar, N. 2011. Hubungan Peran Keluarga dengan Tingkat Kecemasan Anak Usia Sekolah (6-12 Tahun) yang Mengalami Hospitalisasi di Ruang III Rumah Sakit Umum dr. Pirngadi Medan. (http://repository.usu.ac.id/bitstream/12345 6789/27095/6/Abstract.pdf. Diakses tanggal 3 Maret 2016)

Apriliawati, A. 2009. Biblioterapi Dapat Menurunkan Tingkat Kecemasan Anak Usia Sekolah yang Menjalani Hospitalisasi di RSIJ. Nursing Science Jurnal Keperawatan Vol.1.2 : 101108, (https://anitafikumi.files.wordpress.com/ 2015/07/jurnal-biblioterapi-final.pdf.

Diaksses tanggal 5 Maret 2016)

Friedman, M. M.,dkk. 2010. Buku Ajar Keperawatan Keluarga : Riset, Teori dan Praktik Ed. 5. Jakarta : EGC

Gusti, Salvari. 2013. Buku Ajar Asuhan Keperawatan Keluarga. Jakarta : Trans Info Media (TIM).

Hastono, S.P., \& Sabri, L. 2010. Statistik Kesehatan. Jakarta : Rajwali Press.

Hastuti, A. P. 2015. Modul Kuliah Keperawatan Anak : Konsep Hospitalisasi pada Anak dan Keluarga. Politeknik Kesehatan RS dr Soepraoen Malang, Malang, Indonesia.

Hawari. 2006. Psikologi Keperawatan Dasar. Jakarta: EGC

Hidayat, A. A . 2012. Pengantar IImu Keperawatan Anak 1. Jakarta : Salemba Medika. Hal. 6
. 2014. Metode Penelitian Kebidanan

dan Teknik Analisis Data. Jakarta : Salemba Medika

Kementerian Kesehatan Republik Indonesia. 2014. Survei Kesehatan Nasional. (http://www.litbang.depkes.go.id/surkesnas. Diakses tanggal 3 Maret 2016).

Notoatmodjo, S. 2012. Metodologi Penelitian Kesehatan. Jakarta : Rineka Cipta

Nursalam, dkk. 2008. Asuhan Keperawatan Bayi dan Anak. .Jakarta : Salemba Medika 2013. Konsep dan Penerapan Metodologi Penelitian Ilmu Keperawatan: Pedoman Skripsi, Tesis, dan Instrumen Penelitian Keperawatan. Jakarta: Salemba Medika.

Perwira. Ita. 2011. Faktor-faktor yang Mempengaruhi Lama Hari Rawat Pasien di RSUP Persahabatan Jakarta Timur. Skripsi Universitas Indonesia. Hal. 26.

Potter \& Perry. 2005. Buku Ajar Fundamental Keperawatan Volume 1. Edisi 4. Jakarta: EGC.

Purwandari. 2012. Perbedaan Tingkat Kecemasan Pasien Anak Usia Prasekolah Sebelum dan Sesudah Program Mewarnai. Jurnal Keperawatan. Hal. 2.

STIK Siti Khadijah, 2016. Panduan Penulisan Skripsi Program Studi IImu Keperawatan. Palembang : STIK Siti Khadijah.

Stuart, G. W. 2006. Buku Saku Keperawatan Jiwa. Edisi 5. Jakarta. EGC.

Supartini, Y. 2004. Buku Ajar Konsep Dasar Keperawatan Anak. Jakarta : EGC

Winarsih, B, D. 2012. Hubungan Peran Serta Orang Tua dengan Dampak Hospitalisasi pada Anak usia Prasekolah di RSUD RA Kartini Jepara. (http://lib.ui.ac.id. Diakses tanggal 25 Februari 2012).

Wong, et al. 2008. Buku Ajar Keperawatan Pediatrik. Edisi.6, volume 1. Jakarta : EGC

Wong, D., L. 2003. Whaley and Wong's nursing care of infants and children. (7th ed.). St. Louis: Mosby. 